\title{
DIGITALIZÁCIÓ ÉS ÉLETMINŐSÉG
}

\section{DIGITALIZATION AND QUALITY OF LIFE}

\author{
Tátrai Márk János ${ }^{1,3}$, Szabó Zs. Roland ${ }^{2,3}$ \\ 1 kutató \\ tatrai.mark@gmail.com \\ ${ }^{2} \mathrm{PhD}$, habilitált egyetemi docens \\ zsoltroland.szabo@uni-corvinus.hu \\ ${ }^{3}$ Budapesti Corvinus Egyetem Stratégiai és Nemzetközi Menedzsment Kutatóközpont, Budapest
}

\section{ÖSSZEFOGLALÁS}

Kiinduló hipotézisünk szerint, minél magasabb egy adott ország digitális fejlettségi szintje, annál magasabb életminőség érhető el a különböző digitális technológiai előnyök nyújtotta megoldások következtében. Kutatásunk során az Európai Uniós országok Digitális Gazdaság és Társadalom Indexeinek (DESI) és az Életminőség Indexeinek (QLI) kapcsolatát vizsgáltuk 2014 és 2019 között. Erős pozitív kapcsolatot találtunk a digitalizáció mértéke (DESI) és az életminőség szintje (QLI) között.

\section{ABSTRACT}

Our hypothesis was that the higher the level of digital development in a given country, the greater the quality of life it can achieve due to the benefits of various digital technologies. In our research, we investigated the relationship between the Digital Economy and Society Index (DESI) and the Quality of Life Index (QLI) among the EU countries from 2014 to 2019. We found a strong positive relationship between the level of digitalization (DESI) and the quality of life (QLI).

Kulcsszavak: digitalizáció, IKT, transzformáció, jólét, Európai Unió

Keywords: digitalisation, ICT, transformation, quality of life, European Union

\section{DIGITALIZÁCIÓ}

A hétköznapi életben használatos „digitalizáció” fogalomnak három fokozata (melyből valójában csak egy maga a digitalizáció): (1) a digitális feldolgozás, (2) a digitalizáció, végül (3) a digitális transzformáció (Leonhard, 2016). A digitális feldolgozás az analógról a digitális formára való átalakítást jelenti. A digitalizáció annyiban több, mint a digitális feldolgozás, hogy a digitális technológiák 
beépítésre kerülnek a(z üzleti) folyamatokba. A digitális transzformáció során a szervezetek (vállalatok) teljes mértékben digitális müködésre térnek át. A digitalizáció és az ehhez kapcsolódó különböző megoldások jelentős mértékben átrendezik az egyes országok termelési hatékonyságát (Kovács, 2017). Ez pozitív hatással van az adott ország globális versenypiaci helyzetére, így a további, hosszú távú fejlődést is szolgálja.

A digitalizáció a jelenleg folyó negyedik ipari forradalom hajtója. Bojár Gábor (2018) ezzel szemben a negyedik ipari forradalom megnevezést megtévesztőnek tartja. Elgondolása szerint a mai napokban és az elöző évtizedekben végbemenő folyamatok esszenciája inkább az informatikai fejlődési utakkal ragadható meg, és harmadik informatikai forradalomról ír.

\section{AZ ORSZÁGOK DIGITÁLIS FEJLETTSÉGÉNEK MÉRÉSE: DESI}

A DESI öt fö- és számos almutatóból összetevődő kompozit index, amely az európai országok digitális teljesítményét mutatja, illetve az EU-tagállamok digitális versenyképességének alakulását hivatott nyomon követni. A DESI-index főkomponensei: (1) Hálózati összekapcsoltság (Connectivity), (2) Humán tőke / Digitális ismeretek (Human Capital / Digital Skills), (3) Állampolgárok internetes szolgáltatás használata (Use of Internet Services by Citizens), (4) Digitális technológiák beépülése a vállalatok müködésébe (Integration of Digital Technology by Businesses), (5) Digitális közszolgáltatások (Digital Public Services).

2019-ben az EU-s országok közül az első helyet Finnország szerezte meg 69,9-es DESI-értékkel, míg az utolsó helyre Bulgária került 36,2-es DESI-értékkel. Magyarország a huszonnyolc országból a 23. helyet foglalta el 45,4-es DESI értékkel.

\section{A DIGITÁLIS FEJLETTSÉG HATÁSA AZ ÉLETMINŐSÉGRE}

Maga a digitalizáció nem közvetlenül hat az életminőségre, hanem a digitális technológiák serkentik az innovációt, mondja Martin Falk és Frederio Biagi (2015), illetve a digitális technológiák beépülése a vállalatok müködésébe javítja a termelékenységet. A digitalizáció számos új terméket és szolgáltatást tesz elérhetővé a fogyasztók széles rétege számára, melyek javítják az életminőséget. Az életminőség új munkahelyek létrehozásával is javítható, azonban fontos, hogy ez a növekedési modell akkor lehet tartósabb, ha foglalkoztatás-intenzív (Georgescu-Herman, 2019).

Mindezzel párhuzamosan a legszegényebb dolgozói réteg életminősége is jelentősen javulhatna. A politikai döntéshozók számára fontos kihívás a növekedést támogató és a szegényeket támogató politikák összeegyeztetése. Ahogy a World 
Economic Forum 2017-2018-as jelentésében (Schwab, 2017) is szerepel: új növekedési modellre van szükség, ami kiemelten kezeli az egyes országok állampolgárait és életszínvonaluk fejlesztését. Ilyen típusú intézkedések indukálnák majd a későbbi „szándék” helyetti „,valós” növekedést.

Egy ilyen lehetséges növekedési út az újraiparosítás. Nagy Benedek, Udvari Beáta és Lengyel Imre (2019) tanulmánya azt vizsgálta, hogy az EU tíz új tagállamában milyen módon zajlik le az újraiparosítás, amennyiben az már elkezdődött, illetve milyen azonosságok, hasonlóságok fedezhetők fel az EU15 országokban végbemenő folyamatokhoz képest. Mivel nem csupán az EU hivatalos dokumentumaiban, de egyes EU-s tagállamok gazdaságpolitikájában is felmerült már az újraiparosítási szándék, jól látható a kérdés aktualitása. A tanulmány azt is vizsgálta, milyen új munkamegosztást eredményezhet a negyedik ipari forradalom az egyes EU-tagországok között. Dekompozíciós vizsgálat segítségével arra az eredményre jutottak, hogy néhány országot leszámítva (köztük Magyarországot is) a feldolgozóipari szektornövekedés kompenzálja a negatív munkaintenzitási hatást, tehát az ágazati GDP növekedése mellett a foglalkoztatottak száma is növekedni tudott.

Domingo Nevado-Peña és szerzőtársai (2019) tanulmányukban világos kapcsolatot fedeztek fel az adott ország lakosai életminőségének értékelése és az érintett (földrajzi) terület technológiai jellemzői között. Ennek megfelelően az élettel való elégedettségi mutató párhuzamosan nő a különböző technológiák, illetve az IKT- (információs és kommunikációs technológiák) felkészültség magasabb szintjének elérésével. Azon állampolgárok, akik olyan városokban élnek, amelyek magasabb IKT-kapacitással rendelkeznek, illetve a digitális megoldások hasznosítása magas szinten történik, azok inkább igénylik a fenntartható és inkluzív gazdasági növekedést. Végül, az IKT használata a technológiai felhasználók által a közigazgatás hatékonyságának és irányításának jobb értékeléséhez vezet, hangsúlyozva a felhasználók és a közszolgáltatások közötti megértés fontosságát a virtuális szférában.

\section{AZ ÉLETMINŐSÉG MÉRÉSE: QLI}

Az életminőség, illetve tágabb értelemben a jólét mérése relatív. Egyre inkább megkérdőjelezhetővé válik a - sok éve használt, standard - GDP/fö mutató. Kutatók, illetve világszervezetek további soft mutatók bevezetését és azok mérését javasolják, többek között a Well-Being Index (Global Wellness Institute, 2019), a Human Development Index (United Nations, 2019), a Happiness Index (Helliwel és szerzőtársai, 2020). Az ilyen problémákkal foglalkozó mutatók kevésbé makroszinten, mint inkább mikroszinten próbálják a társadalmi jólétet, illetve annak esszenciáját mérni. 
Egy adott ország jólétének alakulása ugyanakkor szoros kapcsolatban áll a munkaerőpiaci teljesítményével. Fülöp Zoltán (2018) tanulmányában az általa vizsgált kutatói vélemények eltérőek voltak a digitalizáció várható munkaerőpiaci hatásairól. Nábelek Fruzsina, Sturcz Anikó és Tóth István János (2016) kb. 500 ezer magyarországi álláshely, míg Carl Benedikt Frey és Michael A. Osborne (2017) az amerikai munkahelyek 47\%-ának megszünését prognosztizálta. Ugyan vannak pesszimista nézetek a digitalizáció okozta munkaerőpiaci (és ezáltal közvetetten a jóléti) hatásokkal kapcsolatosan, ugyanakkor a digitális fejlettségi szint új lehetőségeket is nyithat egy-egy ország esetében, ez által elősegítve a társadalmi jólét fejlődését, az életminőség emelkedését.

Az életminőség mérésére népszerü QLI (Quality of Life Index) hat főkomponensből tevődik össze, melyek a következők: (1) Megélhetési költségek és vásárlóerő (Cost of living and purchasing power), (2) Megfizethető lakhatás (Affordability of housing), (3) Szennyezettségi mutatók (Pollution including air, water, etc.), (4) Bünözési mutatók (Crime rates), (5) Egészségügyi rendszer minősége (Health system quality), (6) Ingázási idő (Traffic [commute times]).

A mutató 0-tól magasabb, pozitív számokat vehet fel, legmagasabb értéke nem érte el a 200-as értéket. A mutató (2019-ben) hetvenegy ország értékeit közölte, melyből Magyarország a 41. helyet foglalja el $(134,47)$. Az legmagasabb értéket Dánia $(198,57)$, míg a legalacsonyabbat Egyiptom $(83,98)$ érte el. Megjegyzendő, hogy a vizsgált időszakok tekintetében a QLI-mutató nem állt rendelkezésre minden EU-tagország esetében minden egyes évben (Ciprus, Csehország, Lettország, Luxemburg és Málta hiányzik).

\section{A DIGITÁLIS FEJLETTSÉG (DESI) ÉS AZ ÉLETMINŐSÉG (QLI) KAPCSOLATA}

Vizsgálatunk három fő megállapításra bontható (1. táblázat). Egyrészről, az azonos időszaki digitális fejlettség és életminőség-mutatók erős pozitív kapcsolatot mutatnak (1. ábra). Tehát a digitálisan fejlett országokban magasabb az életminőség. Másrészről, szintén erős pozitív kapcsolat látszik az említett mutatók 2014-ről 2019-re való változása kapcsán. Tehát a digitális fejlettség növekedése együtt járt az életminőség növekedésével. Harmadrészről, erős negatív kapcsolat mutatható ki az időszaki mutatók és a változásokat mutató mutatók között. Vagyis a digitálisan fejlettebb országokban lassabban nőtt a digitalizáció fejlettsége és az életminőség, mint a kevésbé fejlettekben (közeledés figyelhető meg). Ez érthető, hiszen minél nagyobb szintű egy ország digitális fejlettsége vagy életminősége, annál nehezebb fejlődést elérni mind a digitális fejlettségben, mind az életminőség terén. 
1. táblázat. A digitális fejlettség és az életminőség kapcsolata

\begin{tabular}{|c|c|c|c|c|c|}
\hline & & $\begin{array}{l}\text { 2019-es } \\
\text { digitális } \\
\text { fejlettség }\end{array}$ & $\begin{array}{l}\text { 2019-es } \\
\text { szociális } \\
\text { jólét }\end{array}$ & $\begin{array}{c}\text { Digitális } \\
\text { fejlettség } \\
\text { 2014-ről } \\
\text { 2019-re } \\
\text { történő } \\
\text { változása }\end{array}$ & $\begin{array}{c}\text { Szociális } \\
\text { jólét } \\
\text { 2014-ről } \\
\text { 2019-re } \\
\text { történó } \\
\text { változása }\end{array}$ \\
\hline \multirow[t]{3}{*}{$\begin{array}{l}\text { 2019-es digitális } \\
\text { fejlettség }\end{array}$} & $\begin{array}{l}\text { Pearson- } \\
\text { korreláció }\end{array}$ & 1 &, $835^{* *}$ &,$- 758^{* *}$ &,$- 839^{* *}$ \\
\hline & $\begin{array}{l}\text { Sig. } \\
\text { (kétoldali) }\end{array}$ & & ,000 &, 000 & ,000 \\
\hline & számosság & 28 & 25 & 28 & 23 \\
\hline \multirow[t]{3}{*}{$\begin{array}{l}\text { 2019-es szociális } \\
\text { jólét }\end{array}$} & $\begin{array}{l}\text { Pearson- } \\
\text { korreláció }\end{array}$ &, $835^{* *}$ & 1 &,$- 778^{* *}$ &,$- 790^{* *}$ \\
\hline & $\begin{array}{l}\text { Sig. } \\
\text { (kétoldali) }\end{array}$ & ,000 & & ,000 & ,000 \\
\hline & számosság & 25 & 25 & 25 & 23 \\
\hline \multirow{3}{*}{$\begin{array}{l}\text { Digitális fejlettség } \\
\text { 2014-ről 2019-re } \\
\text { történő változása }\end{array}$} & $\begin{array}{l}\text { Pearson- } \\
\text { korreláció }\end{array}$ &,$- 758^{* *}$ &,$- 778^{* *}$ & 1 &, $675^{* *}$ \\
\hline & $\begin{array}{l}\text { Sig. } \\
\text { (kétoldali) }\end{array}$ &, 000 &, 000 & & ,000 \\
\hline & számosság & 28 & 25 & 28 & 23 \\
\hline \multirow{3}{*}{$\begin{array}{l}\text { Szociális jólét } \\
\text { 2014-ről 2019-re } \\
\text { történő változása }\end{array}$} & $\begin{array}{l}\text { Pearson- } \\
\text { korreláció }\end{array}$ &,$- 839^{* *}$ &,$- 790^{* *}$ &, $675^{* *}$ & 1 \\
\hline & $\begin{array}{l}\text { Sig. } \\
\text { (kétoldali) }\end{array}$ &, 000 &, 000 &, 000 & \\
\hline & számosság & 23 & 23 & 23 & 23 \\
\hline
\end{tabular}

** A korreláció szignifikáns a 0,01-es szinten (kétoldali)

Az adatok forrása Eurostat (2019) és Numbeo (2019)

\section{ZÁRÓ GONDOLATOK}

Vizsgálatunk során az Európai Uniós országok digitális fejlettsége és életminősége közötti összefüggéseket kerestük, és erős kapcsolatokat találtunk. Eredményeink alapján a digitalizáció hozzájárul az életminőség javulásához. Magyarországon a digitális fejlettség, valamint az életminőség alacsonyabb, mint az európai uniós átlag, azonban az eredmények alapján van lehetőség a felzárkózásra. 


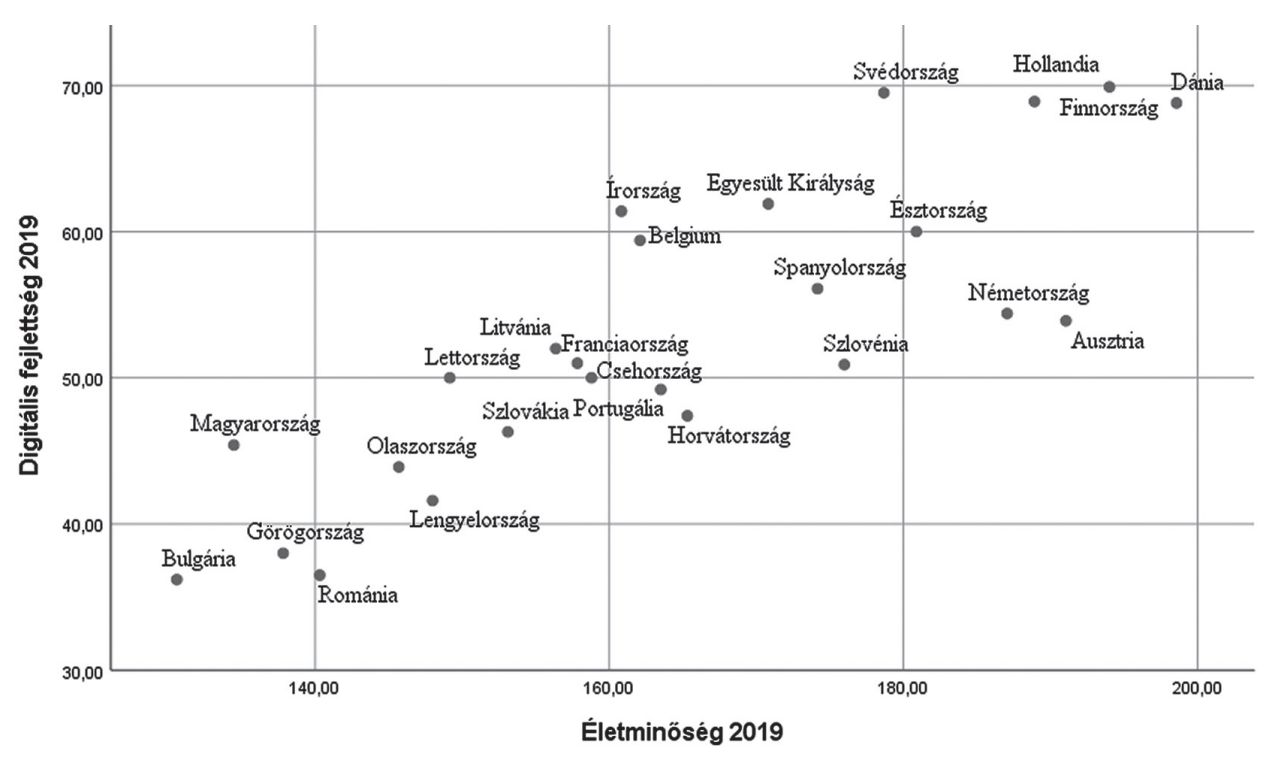

1. ábra. A digitális fejlettség és az életminőség 2019-es értékeinek szórásdiagramja Az adatok forrása Eurostat (2019) és Numbeo (2019)

Az eredmények azt mutatják, hogy a digitalizáció a gazdaság és a társadalom széles rétegeit érinti pozitívan. Tehát a negyedik ipari forradalom nem korlátozódik az informatikára vagy éppen az iparra, hanem valamennyi szervezetet és iparágat érinti. A digitalizáció számos lehetőséget teremt új termékek és szolgáltatások kínálatára és ezen keresztül új munkahelyek teremtésére. Segítségével növelhető a foglalkoztatás és a társadalom kiszorult, leszakadó, szegény rétegeinek a bevonása is.

$\mathrm{S}$ bár összességében pozitív jelenségről beszélhetünk, nem szabad megfeledkezni az esetleges vesztesekről sem. A digitalizáció vesztesei azok az országok, vállalatok és egyének lesznek, akik nem képesek a digitális technológiákat gyorsan elterjeszteni, tevékenységeikbe integrálni, illetve használni. Ezért Magyarország és az itt élők prosperitása szempontjából különösen fontos a digitális transzformáció minél hatékonyabb megvalósítása.

\section{KÖSZÖNETNYILVÁNITTÁS}

A cikk az Innovációs és Technológiai Minisztérium ÚNKP-19-3 kódszámú Új Nemzeti Kiválóság Programjának szakmai támogatásával készült. 


\section{IRODALOM}

Bojár G. (2018)? Negyedik ipari vagy harmadik informatikai forradalom? Az információ sok ezer éves hatalma. Magyar Tudomány, 179, 1, 37-46. DOI: 10.1556/2065.179.2018.1.4, https://mersz. hu/mod/object.php?objazonosito=MaTud(2018)1_4.pdf

Eurostat (2019): The Digital Economy and Society Index (DESI) Data Set. https://ec.europa.eu/ digital-single-market/en/desi (Letöltés: 2019. 11. 13.)

Falk, M. - Biagi, F. (2015): Empirical Studies on the Impacts of ICT Usage in Europe. Institute for Perspective Technological Studies Digital Economy Working Paper, 2015/14. https://ec.europa. $\mathrm{eu} / \mathrm{jrc} / \mathrm{sites} / \mathrm{jrcsh} / \mathrm{files} / \mathrm{JRC} 98693 . \mathrm{pdf}$

Frey, C. B. - Osborne, M. A. (2017): The Future of Employment: How Susceptible Are Jobs to Computerisation? Technological Forecasting and Social Change, 114, 254-280. https://www. oxfordmartin.ox.ac.uk/downloads/academic/The_Future_of_Employment.pdf

Fülöp Z. (2018): Az Ipar 4.0 foglalkoztatásra gyakorolt hatása. Munkaügyi Szemle, 61, 6, 56-64. https://drive.google.com/file/d/1LorAymvtrCYC3iVslNHPz2jA_GCSqyqU/view

Georgescu, A. M. - Herman, E. (2019): Productive Employment for Inclusive and Sustainable Development in European Union Countries: A Multivariate Analysis. Sustainability, 11, 6, 1-19. DOI: 10.3390/su11061771, https://ouci.dntb.gov.ua/en/works/4azB2PM1/

Global Wellness Institute (2019): Well-Being Index. https:/globalwellnessinstitute.org/industry-research/happiness-wellbeing-index/ (Letöltés: 2020. 02. 13.)

Helliwell, J. F. - Layard, R. - Sachs, J. et al. (eds.) (2020): World Happiness Report 2020. New York: Sustainable Development Solutions Network, https://worldhappiness.report/ed/2020/\#read (Letöltés: 2020. 04. 01.)

Kovács O. (2017): Az ipar 4.0 komplexitása - I. Közgazdasági Szemle, 64, 823-851. http://real. mtak.hu/60073/1/07_KovacsA_u.pdf

Leonhard, G. (2016): Technology vs. Humanity. The Coming Clash Between Man and Machine. Fast Future Publishing, San Bernardino, CA.

Nábelek F. - Sturcz A. - Tóth I. J. (2016): Az automatizáció munkaerő-piaci hatásai. Járási munkaerőpiacok automatizációs kitettségének becslése. (MKIK GVI Kutatási Füzetek 2016/4) Budapest: MKIK Gazdaság- és Vállalkozáskutató Intézet, https://epale.ec.europa.eu/sites/default/ files/gvi_-_a_munka_jovoje_2016_elemzes_161023_2-1.pdf

Nagy B. - Udvari B. - Lengyel I. (2019): Újraiparosodás Kelet-Közép-Európában - újraéledő centrum-periféria munkamegosztás? Közgazdasági Szemle, 66, 163-184. DOI: 10.18414/ KSZ.2019.2.163, http://real.mtak.hu/91119/

Nevado-Peña, D. - López-Ruiz, V. R. - Alfaro-Navarro, J. L. (2019): Improving Quality of Life Perception with ICT Use and Technological Capacity in Europe. Technological Forecasting and Social Change, 148, 119734. DOI: 10.1016/j.techfore.2019.119734

Numbeo (2019): Quality of Life Index. https://www.numbeo.com/quality-of-life/ (Letöltés: 2019. 12. 04.)

Schwab, K. (2017): The Global Competitiveness Report 2017-2018. World Economic Forum. https://www.weforum.org/reports/the-global-competitiveness-report-2017-2018 (Letöltés: 2019. 04. 23.)

United Nations (2019): Human Development Index. http://hdr.undp.org/en/content/2019-human-development-index-ranking (Letöltés: 2020. 02. 03.) 